\title{
Social Science in Court
}

\author{
On "Eyewitness Experts" and Other Issues*
}

\author{
Richard O. Lempert $†$
}

This article discusses the role of social science in legal proceedings with special attention to the ethical situation of the expert psychologist asked to testify about the reliability of an eyewitness identification. It argues that in this area as in others one cannot discuss the ethics of expert psychological testimony without attending to the quality of the research and theory on which the testimony is based. It also identifies as considerations that bear on the propriety of such testimony the information the fact finder is likely to receive in its absence and the factual guilt of the defendant. The paper goes on to discuss the relationship between law and social science more generally. It argues that ultimately courts do and should have the last word regarding the place of social science in legal proceedings.

\section{INTRODUCTION}

The reaction of courts to social science evidence is frequently an uneasy one. What social science tells us is too often closely related to what we all know. If social science evidence is congruent with what we know the evidence appears to serve little purpose, yet if the evidence is incongruent, it tends to be regarded with suspicion. This is not simply because the "truths" of the social sciences can seldom be demonstrated with the precision or elegance of physical science "truths." It is also because too often social science "truths" as they have been marketed to the public (usually in semipopular books and magazines rather than through the courts) have later turned out to be either false or, if not false, highly contingent on circumstances that were not originally clearly specified. In this article I would like to pursue the topic of the appropriate role for social scientific evidence in the judicial system with special attention to the question of what

\footnotetext{
* I would like to thank Lisa Lett for her help in transcribing a garbled tape of my oral remarks and Joyce Reese and Gail Ristow for their valuable assistance in preparing the finished manuscript. $\dagger$ Professor of Law and Sociology, University of Michigan.
} 
expert psychologists can and should be allowed to tell courts about the likely credibility of eyewitness testimony. I focus on this topic by way of example because interest in this topic unites most of those participating in this symposium issue of Law and Human Behavior.

Perhaps because the general issue that the symposium addresses concerns ethical considerations that apply whenever experimental psychologists are asked to testify in court, no paper systematically considers what we know about the subject matter of expert psychological testimony. In particular no paper has as its central focus the question of what psychologists can or cannot tell us about the factors that make for accurate or inaccurate eyewitness identifications. Although the common expertise and mixture of viewpoints on this topic quite naturally infuse many of the papers in this symposium issue and was reflected in much of the discussion at the conference for which these papers were first prepared, I think that explicit attention to research on memory and perception as it relates to the likely validity of eyewitness identification (taking this as an example) is a requisite for intelligent discussion. Both establishing areas of consensus and pinpointing sources of disagreement are to my mind necessary preludes to determining the ethical duty of psychologists asked to testify on particular matters. Indeed, if the goal is to state what ethics requires, I do not know how this can be done unless we know the common assumptions that exist and the divergent beliefs we must confront.

\section{THE IMPORTANCE OF THEORY}

I want to make two observations that pertain to this topic. The first is to note that the word "theory" is often absent in discussions of the appropriateness of generalizing from the laboratory to the courtroom setting. Instead such discussions typically center on what is called external or ecological validity. The key to generalization in science, however, is through theory. While I do not want to denigrate the importance of external validity in applied psychological research, we can also learn from research that appears far removed from the applied setting. What is crucial is that a body of research, whatever the external validity of the constituent studies, fit consistently into a more encompassing theory. If a well-grounded theory applies, in principle, to situations that arise at trials, there is a basis for expert psychological testimony. Thus, a crucial question that must be confronted in deciding whether psychologists may properly testify as experts on eyewitness identification is whether the profession has managed to build theories from which we can with some confidence generalize to the trial situation.

I think that what separates the different positions that people take on the propriety of psychologists testifying as experts on eyewitness identification turns largely on the answers different people give to this question. Some are confident that we can bring to bear on the issue of eyewitness credibility a reasonably broad body of well-grounded theory. Others believe that the research relating to witness credibility (and I include here basic research on memory and perception) is so 
ambiguous and inconsistent that it is premature to even suggest that we are approaching theoretical closure.

I take a middle ground. I think that different judgments are appropriate in different areas. I believe that some of the conclusions eyewitness experts commonly reach have, at best, a tenuous theoretical basis. Two examples are testimony about the unreliability of cross-racial identifications ${ }^{1}$ and the phenomenon called weapon focus. I am uncomfortable with receiving testimony in these areas because the literature that attempts to explore these matters empirically is sparse and has yielded mixed results. To the extent that there are strong theoretical bases for what psychologists tell us about such matters, the theories appear rooted in common sense rather than systematic psychological experimentation. I do not deny that those who testify to the special difficulties that affect, for example, cross-racial identification, can point to some good psychological research; but "they all look alike to me," which is the message that is conveyed, remains essentially a common sense proposition. Not only are there inconsistencies in the research that bears on the "look alike" proposition, but if the phenomenon exists, we do not yet have an adequately grounded psychological explanation.

People, psychologists included, approach research with different values and strong preconceptions. This can lead them to dismiss research that does not accord with their common sense and to acclaim research that does. In principle there is nothing wrong with this. Psychologists, if anyone, should be good Bayesians. However, when expert psychological testimony is in large measure just common sense that jurors share, and systematic psychological research is conflicting, the jury is not greatly aided by expert testimony and may be misled.

At the other extreme are psychological theories that are rooted in studies which, from the standpoint of the courtroom, have low ecological validity but which are so consistently supported or make such good psychological sense that juries should be informed of the experts' point of view. The effect of stress on perceptual accuracy comes immediately to mind. Although most of the studies that tend to show that stress degrades perceptual performance do not expose subjects to the kinds of stress witnesses to crimes face, the research seems sufficiently consistent and sufficiently related to the effects that stress has on other kinds of performance, that expert testimony on the way in which stress is likely to affect a witness's perceptual accuracy and later recall is, in my opinion, justified. The testimony may be particularly valuable because some people's common sense suggests that matters perceived under conditions of great stress are seared into the brain.

Now I may be wrong in my particular examples, for unlike most contributors

\footnotetext{
${ }^{1}$ I am thinking here of cross-racial identifications generally. Psychologists have a better basis for suggesting there are special dangers to identifications of blacks by whites than they do when identification involve other cross-racial configurations. This reflects the amount and ecological validity of the research that has been done rather than a satisfactory general theory. Indeed, with a satisfactory theory an understanding of the relative strengths and weaknesses of particular types of same and cross-racial identifications should be possible.
} 
to this symposium issue I am not a psychologist and may not be sufficiently familiar with the relevant literature. But even if my examples do not persuade, I believe my basic point is sound. The issue that is worth discussing is not whether psychologists should or should not be allowed to testify as experts on the foibles of eyewitness identification. Rather, it is how well-rooted in psychological theory are the generalizations that expert psychologists are called on to make in front of the jury.

\section{REDUNDANCY AND ACCURACY}

A second matter that is not discussed in the other papers which I would like to address is the question of when eyewitness testimony identifying a defendant as the criminal is likely to be accurate. In a probabilistic sense at least, I believe the answer is simple. The identification testimony of eyewitnesses is, by and large, quite good, in the sense of being accurate, when there is a substantial body of other evidence that points to the defendant's guilt. Eyewitness identifications are probably not very good, in the sense that there is a substantial possibility that they are inaccurate, when there is little evidence apart from the eyewitness testimony that suggests the defendant is guilty. Assuming I am right, there is the interesting implication that the likely accuracy of an eyewitness may be better judged by the way his or her evidence accords with other evidence in the case than by the psychodynamic features of the observational or testimonal setting.

What follows from this? If our goal is to maximize the probability of correct jury verdicts, the argument suggests that experts testifying to the foibles of eyewitness identification should be most welcome when the evidence against the defendant, apart from the eyewitness testimony, is weak. Indeed, in increasing the skepticism with which jurors approach the eyewitness testimony, the expert may serve to counterbalance a known failure of human reasoning, namely, the common tendency to insufficiently attend to the probative value of "absent" information-in my example the fact that there is little evidence apart from the eyewitness identification suggesting that the defendant is guilty. Conversely, where there is considerable circumstantial evidence suggesting the defendant's guilt, another failure of human rationality becomes salient. People do not cumulate evidence in a Bayesian-rational way, in that they often fail to appreciate how extremely probative a consistent body of evidence can be. When the inculpatory circumstantial evidence is substantial, there is good reason to bar testimony that casts doubt on the likely accuracy of eyewitnesses. Not only is eyewitness testimony consistent with highly probative circumstantial evidence likely to be accurate, whatever its apparent flaws, but any tendency to overvalue the eyewitness testimony may correct, in a loose way at least, for natural tendencies to undervalue the cumulative impact of inculpatory circumstantial evidence. The net result is likely to be that justice, over the run of cases, is enhanced if experts on eyewitness identification are allowed to testify when the evidence against the defendant is, apart from the eyewitness testimony, weak, and barred from testifying when the other evidence in the case is strong. 
Now if this intuition is correct, it may be that our legal system, which makes the admission of "eyewitness expert" testimony discretionary, is well suited to enhancing justice. I venture the hypothesis-not having done the systematic research needed to support it-that judges apply a rule of thumb when the testimony of psychological experts on eyewitness identification is proffered. If they think the prosecution's case is weak, they tend to allow the expert testimony, and if they think the prosecution's case is strong, they tend to exclude it. The goal in each case is the same: to do justice. I do not want to be a Pollyanna, but I think we have in practice a better system than an analysis of the formal legal rules that govern the admissibility of expert testimony in this area might suggest. Indeed, one court seems to have adopted the position I espouse here. ${ }^{2}$ The case, People v. McDonald involved a California man who had been found guilty of murder in the course of a street robbery and sentenced to death solely on the basis of the testimony of seven eyewitnesses. The eyewitnesses varied in the certainty of their identification, many had had a partially obstructed view of the incident, several had not picked the defendant out when first presented with a six-to tenperson photo array, and an eighth eyewitness was confident that the defendant was not the man at the scene. The defendant in the case presented six alibi witnesses whose testimony, if believed, meant that the defendant could not possibly have committed the crime.

Justice Stanley Mosk, writing for a unanimous California Supreme Court held:

When an eyewitness identification of the defendant is a key element of the prosecution's case but is not substantially corroborated by evidence giving it independent reliability, and the defendant offers qualified expert testimony on specific psychological factors shown by the record that could have affected the accuracy of the identification but are not likely to be fully known to or understood by the jury, it will ordinarily be error to exclude that testimony (208 Cal. Rptr. 236, 254; emphasis added).

I want to make two further points before I leave this issue. First, discussions about the admissibility of expert testimony in the eyewitness area typically proceed on the assumption that if experts did not testify about eyewitness testimony nothing would be said about the quality of the eyewitness's report. This assumption is often-indeed my guess is almost always-mistaken. Attorneys argue issues of eyewitness credibility whether or not experts testify on the topic. However tenuous the psychological foundations of expert testimony, expert opinion as a whole is likely to provide a better basis for judging eyewitness credibility than the folk wisdom that zealous advocates share. For example, in an evidence book I coauthored (Lempert and Saltzburg, 1982) there is a transcript of a case tried in 1967 in which the prosecution sought and secured the death sentence for rape. The crucial evidence in the case was the eyewitness testimony of the victim, a 65-year-old white woman assaulted by a black man. For all but a few

\footnotetext{
${ }^{2}$ My reflections are independent on the court's views and vice versa, since my observations preceded the decisions in McDonald by about a year but were not available to the judges who decided that case.
} 
seconds this woman saw her assailant only in a room that was dimly illuminated by lights in other rooms. In arguing for the adequacy of the eyewitness identification, the prosecutor told the jury, "There is not a man on this jury, if you had to come in close contact with him under heat of passion or excitement but what you would remember his face as long as you live" (1176). Perhaps some psychologists would dispute the idea that stress interferes with perceptions and later recall, but I would be surprised if any would agree with this prosecutor's armchair psychology. Too often the debate over the desirability of allowing psychologists to testify as experts on eyewitness identification proceeds as if the choice were between the jury's uneducated common sense and generalizations that some think are not adequately supported by psychological research. In fact, the choice may be between expert testimony that may in some respects by controversial and the self-interested folk wisdom of attorneys that clearly misstates what we do know.

My second point may be illustrated with the aid of an extreme example. Consider a situation where an elderly white woman caught a momentary glance of a black robber who shot at her as he was fleeing a bank he had just robbed at dusk. The witness after telling the police that the robber was of average height picked the defendant, who it turns out was a busboy at a restaurant she frequents, from a lineup in which everyone but the defendant, who is $5^{\prime} 9^{\prime \prime}$, was $6^{\prime} 2^{\prime \prime}$ tall or taller. The witness is willing to testify that she is absolutely certain the defendant robbed the bank. Here is ample grist for any expert psychologist's mill. Most psychologists would agree that the witness's certainty has no bearing on her accuracy, and many would argue that her lineup identification is worthless or close to it. But assume that all the money taken from the bank was found under the defendant's bed in his one room apartment, that ballistic tests show that a gun taken from the defendant is the gun the robber used, and that the defendant has confessed to the crime. The only problem with the state's case is that the defendant's confession has been suppressed as involuntary, and the evidence pertaining to the gun and money has been excluded as the fruit of an illegal search and seizure. Thus, the government's case rests heavily on the eyewitness testimony.

I believe that a psychologist who voluntarily testified for the defendant in this case would be acting unethically. More generally, I think it is or should be a breach of ethics for a psychologist to volunteer testimony that calls the reliability of an eyewitness identification into question when the psychologist knows-from whatever source-that the identification is in fact correct. ${ }^{3}$ I say this even though the eyewitness' testimony is, as in my example, fraught with the potential for error, and the psychologist's testimony is carefully limited and honest. The psychologist's role as expert is to help the trier of fact reach an accurate conclusion about whether the eyewitness's testimony can be trusted in the instant case. When the psychologist knows that his or her testimony, which is true in a statis-

\footnotetext{
${ }^{3}$ A difficult question, which I am not addressing, arises if the witness on some moral ground is opposed to the trial or punishment of the defendant for the crime in question. The ethical question is also more complex and hence not considered here if the eyewitness is not testifying honestly or if his recall has been intentionally manipulated by the police.
} 
tical sense, will, if accepted, lead to an inaccurate judgment in the case at hand, the psychologist has an obligation not to give it. There is no reason for the psychologist to be a knowing instrument of injustice.

In this the expert psychologist differs from the lawyer. We would almost certainly convict more guilty people if lawyers refused their cases. However, there is a constitutional right to counsel along with a concomitant obligation on lawyers to defend the guilty as well as the innocent and to take actions, such as motions to suppress evidence, that will lead to the acquittal of factually guilty clients. The expert has no such obligation to aid the guilty. Nor does a system in which the state must prove guilt beyond a reasonable doubt require that experts participate when their testimony can only mislead the fact finder. This too distinguishes experts from lawyers, whose presence has come to be seen as essential to the viability of such a system. ${ }^{4}$

My example is, of course, far clearer with respect to the defendant's factual guilt than most cases expert psychologists will confront. Ordinarily I think the ethical expert must respect his or her own subjective judgment. If the expert believes the defendant is innocent or that his guilt, as a factual matter, is genuinely in doubt, I see no special problem with the decision to testify. If the expert believes the defendant is in fact guilty, even if the evidence of guilt might not be sufficient to persuade a jury or another expert, I believe that the expert has defined for him or herself the course of injustice, and that the ethical expert will avoid it.

\section{SOCIAL SCIENCE IN THE COURTS}

Now let me change the focus of my remarks and address some broader issues about the place that testimony by social scientists has in our trial system. My basic theme is captured by the familiar joke about the five-hundred pound gorilla. The question is, "What does a five-hundred pound gorilla do when he meets you in a dark alley at midnight?" The answer is "Anything he wants to do." When social science encounters the trial system, the law is the gorilla. The law sets the parameters for what the social scientist can do. This, of course, does not mean that social science can not influence what the law allows. If you want to attract a gorilla, you can hold up a banana. The problem is that if the gorilla is attracted it may take the entire bunch of bananas including some that are not ripe or those you were saving for yourself, and it may take your hand off in the pro-

\footnotetext{
${ }^{4}$ Criminal defendants do have a right under the compulsory process clause of the Sixth Amendment to secure the testimony of witnesses in their favor. At most this imposes on a witness an obligation to testify truthfully when subpoenaed. It does not speak to the situation of the witness who voluntarily testifies. Moreover, the clause does not give a witness a right to secure any testimony in his favor. Perjury, however helpful, remains forbidden. Whether there is a right to honest testimony which a witness would rather not give because he or she knows it will be misleading in context is a question that no court to my knowledge has addressed. Moreover, it is unclear what the compulsory process clause implies when an expert is unwilling to testify at the defendant's behest.
} 
cess. One moral is that when social scientists seek to inform the law, they should proceed carefully.

\section{THE LEGAL PERSPECTIVE}

The law may attend to what social scientists tell it, but it will view the social scientist's contribution from a legal perspective which may be quite different from the scientific perspective and carry some unanticipated implications. Consider, for example, the article by McCloskey and Egeth (1983), which in disputing the potential contribution of expert testimony on eyewitness identification provided some of the impetus for the conference that led to this special issue of Law and Human Behavior. I regard this article as an important and helpful one in the sense that it stimulates a potentially valuable reexamination of the body of "eyewitness research" and properly questions whether the theories that eyewitness experts advance are in fact grounded in careful psychological studies. In addition, the debate it has generated among psychologists will help set the agenda for the next few rounds of experimentation. While I do not agree with a number of McCloskey and Egeth's conclusions, I think psychology will benefit substantially from further thinking about what many had treated as closed issues.

From a psychological or social science standpoint all this is fine. It is through disputes like that which McCloskey and Egeth generate that science advances and we get closer to social science truths. But consider what might happen when an article like this gets into the legal system, as it might if a prosecutor calls a court's attention to it in an effort to exclude the testimony of a defendant's psychological expert. If the jurisdiction applies the Frye test, as many do, the crucial question will not be whether McCloskey and Egeth are closer to the truth than psychologists who take opposing positions. Nor will it be whether the contribution that psychology can make is somewhere in between the positions espoused by the protagonists in this debate. Under the Frye test the crucial question is whether the theory on which the testimony is based is generally accepted in the relevant scientific community, which in this case is psychology. Thus, in law, unlike psychology, there is a danger that McCloskey and Egeth will win hands down, by default as it were. Just by creating a controversy in an important journal they provide prosecutors with ammunition that some courts might consider sufficient to show that the theories that underlie the testimony of eyewitness experts are not generally accepted within the psychological community. ${ }^{5}$

\footnotetext{
${ }^{5}$ Their article was not sufficient to persuade the California Supreme Court in People v. McDonald. The McDonald court argued that Frye applies only to novel devices or processes like lie detectors and hypnosis. They argued that Frye does not apply to the testimony of psychological experts on eyewitness testimony because no novel scientific methods are involved. I regard this effort to distinguish Frye as the weakest part of the decision. I expect that if the judges thought that the psycholog. ical community did not regard the testimony that experts on eyewitness identification give as generally valid, they would not have reversed the decision below. Despite McDonald, a court might reasonably cite the work of critics like McCloskey and Egeth as evidence that the Frye test was not fulfilled.
} 
What the law should be concerned with is the merits of the positions taken by the disputants and not the mere existence of a dispute. We know that the opinions of psychologists on what "eyewitness experts" have to offer differ substantially. Some would ban their testimony while others seem to feel that there is hardly an issue on which psychologists cannot enlighten jurors. The most defensible position as I have argued above is likely to be somewhere in the middle. On some issues but not on others psychologists can provide jurors with reliable in. formation they would not otherwise appreciate.

Yet if the Frye test controls, the courts may never come to ask whether there are any reliable middle positions. It is not, however, clear that the Frye test will dominate. The Federal Rules of Evidence and its state counterparts appear to apply a more general test of relevance-namely, will the jury be helped-to the admissibility of expert opinion. But it is certainly premature to proclaim the death of Frye, for it is cited and followed by many courts, even in federal rules jurisdictions. Furthermore, there is a justification for Frye. If psychologists cannot arrive at a consensus on the value of such testimony, how can a psychologically naive judge, whose primary task is to resolve the case in front of him, be expected to value it properly?

If we as social scientists should be concerned with the merits of the controversy, what the courts should be concerned with is whether the jury will be aided -that is, be able to better evaluate eyewitness testimony over the long run-if psychologists are allowed to testify. The questions are closely related but are not the same. Evidence which is sufficiently mixed so that the scientific community is properly unwilling to treat an hypothesis as proven may nevertheless provide knowledge that is sufficiently more reliable than the average juror's common sense that the jury is aided by learning of it. For example, even if a complete lack of association between witness accuracy and witness confidence has not been shown, it appears clear that any relationship is far weaker than most people would expect.

\section{THE MISSING DIMENSION}

Psychologists could better contribute to decisions that the law must reach if they expanded their research horizons to encompass the questions of how jurors currently evaluate eyewitness testimony and how their evaluations are affected when experts appear. Some researchers are beginning to examine these questions, but as is often the case when social scientists mark out a new area for exploration, the early research tends to be crude. Studying the effects of eyewitness and eyewitness expert testimony on the jury requires close attention to ecological validity. In particular, experimental subjects should represent the jury eligible population and deliberations should be allowed. Also actual jury trials should be observed and the jurors questioned. These aspects of ecological validity are so important because the knowledge base of most jurors is likely to differ substantially from that of more accessible student subjects and because groups use information in ways that are not captured by the sum of what individual members know. 


\section{THE IMPORTANCE OF RESEARCH}

Courts not only define the issues on which social science research is relevant; they also decide what weight to give it. In doing so, they are clearly influenced by the respect accorded the research within the relevant social science discipline. But they are not controlled by the discipline's views. Furthermore, courts are not above using social science in the same way in which they use some case precedent and law review articles: to justify decisions that would have been exactly the same had the scholarship or precedent never existed. This latter use occurs largely at the appellate rather than the trial level, and I want to address my next few remarks to it.

I am always struck by the way the social science community reacts to judicial references to social science information, particularly references by the Supreme Court. It is as if social scientists have an urge to prove the practical relevance of social science in general and of their own work in particular, and as if there is no greater proof of that relevance than citation by the Supreme Court. This is not only true of those whose work is cited, but it is also true, and perhaps even more so, of those who criticize the Court for its apparent reliance on social science research. Both act as if the research was important to the decision and for this reason socially important. Those who take this view rarely understand how courts operate.

Most social science research is only mentioned in the footnotes to an opinion, and a footnote is just that. For example, it is clear that Brown v. Board of Education would have come out the same way had the social science brief never been filed and the famous footnote 11 never appeared. The groundwork for Brown was laid not in Kenneth Clark's laboratory, but in a series of cases which declared such things as the white primary and segregated law schools unconstitutional. To take another example, consider the jury size cases, Williams $v$. Florida, 399 U.S. 78 (1970) and Colgrove v. Battin, 413 U.S. 149 (1973). The Justices who wrote these opinions have been criticized, both for misreading psychological research and for relying on obviously flawed studies. These criticisms are fair ones, but the posited reliance almost certainly did not exist. It is most unlikely that the Justices carefully perused the relevant social science research before casting their votes in conference and assigning an opinion. Instead, they cast their votes based on their common sense judgments of what different jury sizes implied for values they thought the Constitution was intended to preserve. The social science entered in when a Justice's law clerk, a recent law graduate lacking social science expertise, was assigned to draft or substantiate an opinion expressing the Court's will. The clerk, no doubt, searched for social science studies that supported the decision since the relevance of social science was obvious. This process, if I am correct, is not much different from what it would have been had the search been for support in legal precedents or treatises.

Clerks more than occasionally mischaracterize precedents or legal arguments, and they are selected for their expertise in reading this literature. Thus, it is no wonder that some of the social science cited in Williams and Colgrove was in part misinterpreted or worthless, and it should be a comfort to know that these 
mistakes almost certainly did not affect the decision. The clerk, of course, remains anonymous, but pity the poor Justice when the whole community of social scientists rushes to the attack as if the misreading of social science led to a mistaken decision.

I do not mean by this analysis to suggest that social scientists should ignore courts that miscite or otherwise misuse social science findings. The case for such criticism does not turn entirely or even largely on whether or not courts are influenced by the social science they cite. Social scientists rather than lawyers are the appropriate judges of what courts may appropriately conclude from empirical research and scientific theory, and only by paying close attention to what courts say, can we, over the long run, improve the way social science is used. All I am arguing here is that we keep the judicial use of social science in proper perspective. We should not exaggerate the contributions of social science research to judicial decisions.

A proper perspective on the judicial use of social science also requires the critic to appreciate the fact that courts, unlike social scientists, must reach a conclusion now and should draw on the best available knowledge. A failure to appreciate this not only leads to unmerited criticism of judicial opinions, but sometimes means that courts are held to standards that are not applied rigorously within the scientific community. Let me illustrate this point.

I expect the reason I was asked to participate in this symposium is ultimately traceable to an article I wrote on the jury size issue (Lempert, 1975). This article first brought my name to the attention of psychologists. The article discussed the Williams case and the issue of whether six-member juries were qualitatively different from twelve-member juries. When I began the article, I vaguely remembered a literature on group size that I had read as a graduate student which I thought directly addressed this issue. I expected to be able to go to this literature, find studies of six-member versus twelve-member groups and extrapolate from them to the issues that concerned or should have concerned the Williams court. So I proceeded to read every article I could find that discussed size effects in small groups. I found numbers of studies of two and three person groups, some studies of groups with four, five or six members, and a few studies of larger groups. There was almost nothing in this sizable literature that compared the performance of six-member and twelve-member groups. So what did I do-forget the article? Not after the investment I had made! I extrapolated from what was there. I developed more general theories. I made predictions. I think it is fair to say that not only was the resulting article well received by professional psychologists, but virtually all the research comparing six-person to twelve-person juries that came afterwards confirmed my generalizations and predictions. In other words, my intuition that I could use studies that compared groups of two, three, four, and six to develop sound theory about the likely differences between groups of six and twelve appears to have been correct.

Compare the reaction to this article and my generalizations to the reactions to Justice Blackmun's use of social science in Ballew v. Georgia, 435 U.S. 223 (1978). (I should note that unlike Williams, social science arguably influenced this opinion since references to social science are not confined to the footnotes but 
are an integral part of the text.) To overgeneralize only slightly, Justice Blackmun in Ballew drew on the post-Williams literature on jury size to hold that while six-member juries were constitutional, juries of five were impermissibly small. He was criticized by social scientists who pointed out that he had relied on studies, almost all of which compared juries of six and twelve, to reach conclusions about the likely differences between juries of six and five. Yet we as social scientists had not provided more apposite research (we seem always to study the problem the Court disposed of wrongly yesterday), and surely Justice Blackmun's generalization down is as reasonable as my generalization up. Indeed, it is probably more so. It is at least plausible that after a certain size (and one might before the recent research have argued that it was six) additional group members do not substantially affect the dynamics of group decision-making processes. Yet we know that the dynamics in dyads differ dramatically from the dynamics in triads and these in turn differ substantially from what occurs in fourperson groups. While the difference between six- and five-person juries may not be as great as the difference between six-and twelve-person juries, surely it is reasonable to generalize from the twelve- versus six-person studies to the likelihood of further important differences as juries get progressively smaller.

The reaction to Ballew suggests that Justice Blackmun, because he lacks a Ph.D., lacks a license to draw reasonable theoretical generalizations, or, to be perhaps fairer to the critics, the adverse commentary may be because Blackmun, in deciding cases, does not specify the justification for his generalizations as carefully as a social scientist would when writing for a social science journal. In any case, my message is the same. Critics of the judicial use of social science should appreciate the problems faced by decision makers who must reach decisions whatever the deficiencies in the current stock of knowledge, and they should make allowances for the fact that cultural and contextual factors mean that judicial writing is unlikely to reveal the kind of reasoning from research that is customary in social science. Furthermore, it is not necessary that judges be as careful with their social science as social scientists are, for specific social science findings will be only one of a number of factors that influence a court, and usually the precise findings will not be very important, so long as the idea is generally sound.

\section{FACT FINDING OR APPEAL}

In my comments thus far, I have distinguished between the use of social science experts by courts that must resolve factual issues at trials and the use of social science research to make law on appeal. The distinction is fundamental and in any discussion of social science and the law must always be kept in mind. Juries and trial judges hearing cases without juries do not, by and large, decide any great policy issues. They decide issues of fact. Appellate courts decide policy issues, for they interpret and make law.

How we as social scientists participate in the legal process, what we can say 
and how we can say it, depend on whether we are concerned with influencing fact finding at trial or law making on appeal. If the goal is to influence appellate decision making one is, generally speaking, well advised to publish in Psychology Today, or better still the Atlantic or the New York Times Magazine, rather than in any of the peer-referred journals that count so heavily when tenure is at stake. Publications in prestigious professional journals may be cited by courts, but the citation is unlikely to have really mattered. Publications in journals that nourish the popular intellect are unlikely to be cited (after all, what court wants to acknowledge relying on the Atlantic for scientific enlightenment?) but may well influence the judiciary's general perception of reality and so affect the perspective in which judges see the case. Consider Henry Kalven's (1968) question, "For social science learning to have an impact on the living law, will it first have to become popular learning ... ?" (68, emphasis in original). The question as I understand it, is rhetorical, and the expected answer is, "Yes." Thus, if psychologists should establish the general unreliability of eyewitness testimony and if that general unreliability should become common knowledge, the courts will be likely to reach decisions, such as decisions mandating the admissibility of expert psychological testimony, that presuppose that unreliability. (Note the irony here: If knowledge of the foibles of eyewitness testimony were genuinely common rather than confined to an educated elite, expert testimony on the subject should not be admissible because it would not substantially aid the jury.)

\section{SOCIAL SCIENCE AS RATIONALE}

The other side of this is that until scientific findings are generally accepted, at least among the educated elite, we must be wary of courts that defer to social science. The deference may be due less to the implications of scientific research than to the court's desire to achieve independently defined ends. By way of illustration, consider the case of Chapple v. State, 135 Ariz, 281 (1983). In Chapple, the Arizona Supreme Court became the first appellate court anywhere (The California court in McDonald is the second) to hold that a trial judge abused his discretion when he barred an expert on eyewitness identification from testifying. Chapple is interesting not so much for its result as for the fact that it is hard to imagine a worse case for departing from established precedent. The typical eyewitness identification involves either a victim who perceives a criminal for several stressful minutes or a casual observer who gets a relatively brief glimpse of the perpetrator of a crime. Psychologists may have something to offer the jury in the former case because there are substantial theoretical reasons to believe that stress interferes with perception, and they may have something to offer in the latter case because it is the paradigm for the most ecologically valid research done on this topic. But Chapple involved neither of these situations. Instead it involved two participants in a homicide testifying against an alleged coparticipant. While the alleged coparticipant was originally a stranger to the witnesses, by the time they parted they had been together for several days in a variety of 
settings. Some of these settings, like killing together, were, no doubt, stressful; others like riding from an airport together or sharing a beer were almost certainly not.

Some features of the identification, like the possibility of suggestive questioning and the danger of unconscious transference from a photo spread that did not yield an identification, relate to matters on which psychologists often have something to offer juries. However, resistance to suggestion and the incidence of unconscious transference almost certainly interact with the time period over which the witness views the target and the conditions under which the observations occur. In the absence of good psychological research showing only a minimal interaction effect, it is plausible if not likely that even well-established threats to the validity of eyewitness identifications are of little import when an acquaintance lasts for several days as it did in Chapple. Certainly an expert psychologist has little in the way of ecologically valid research or well-grounded theory to offer a jury on the facts of this case.

Yet Chapple established a precedent for the admission of expert testimony that other appellate courts confronted with the exclusion of apparently more informative expert testimony had refused to endorse. Why did the Arizona Supreme Court choose this unpropitious case to break new ground? I can only speculate, but my guess is that the Arizona Supreme Court believed that the eyewitnesses were lying and that Chapple was innocent. ${ }^{6}$ Chapple had what seemed to be a very good alibi; there is little reason to suppose he would have participated in the murder, and the eyewitnesses appeared to have benefitted from a plea bargain that gave them an incentive to identify someone. In addition, there is a hint in the briefs that there was a more likely suspect who was never energetically pursued. From this perspective, the decision is not unusual. In cases where an injustice appears to have been done below, appellate courts commonly search for some evidentiary error at trial that will justify overturning the conviction. Here they focused in part, most unfortunately perhaps, on the exclusion of the eyewitness report.

The decision in Chapple will be unfortunate if psychologists, particularly those opposed to the admission of expert testimony on eyewitness identification, find in Chapple an occasion to chastise a court for its misunderstanding of what psychology can offer and seek to draw from critiques of Chapple the lesson that such testimony should never be admitted. To do this is, if anything, even less defensible than the attempt to generalize from the classic research on eyewitness testimony to the situation in Chapple. The issue is an important one, but the debate should proceed with more typical cases in mind. If I am correct in my speculation about what motivated the Chapple court, the admissibility of expert eyewitness identification testimony was never really the issue.

From the lawyer's standpoint the question whether to allow psychologists to testify on eyewitness credibility involves no great policy issue but is simply a

\footnotetext{
${ }^{6} \mathrm{~A}$ view of the merits may also have influenced the California Supreme Court in McDonald. Reading the opinion in $M c$ Donald one senses that the court probably thought that there was a good chance that an innocent man had been sentenced to death.
} 
matter of evidence law. Yet prosaic or not, the issue is important. Life, liberty and the release of dangerous criminals to the street are among the values at stake. What should the courts do? Should experts on eyewitness credibility be routinely allowed to testify? Should they be always barred? Or is an ad hoc balancing approach appropriate? Let me duck these questions with another story. Casey Stengel, who managed the Yankees while I was growing up, claimed at one time to have dreamed that he died and went to heaven. The first thing that happened when God saw him was that God said to Casey, "I'm so glad your're here. I want you to organize a baseball team. Here are your players." Casey looked out and he saw Babe Ruth, Ty Cobb, Walter Johnson, Christy Mathewson and others like them, the greatest players of all time. So he built a team and worked with his players-they had gotten a little out of shape over the years-until they were in their peak condition. Just then-just as Casey was wondering who this heavenly host could possibly play - the phone rang. It was Satan, calling to challenge the Lord's team to a game. Casey was delighted and accepted immediately, but then he added, "You don't understand, you don't have a chance. I've got all the players." Satan replied, "No, you don't understand. I've got all the umpires." The umpire exists, whether social scientists like it or not; it is the legal system. It will be the law and not psychology that will decide if, and under what conditions, experts on eyewitness identification will be allowed to testify. As in baseball, little is to be gained from arguing with the umpire. But this umpire, perhaps unlike its baseball counterpart, can be educated. It is here that psychology can make its greatest contribution.

\section{REFERENCES}

Kalven, H. (1968). The quest for the middle range: Empirical inquiry and legal policy. In G. C. Hazard, Jr. (Ed.), Law in a changing America. Englewood Cliffs: Prentice-Hall.

Lempert, R. O. (1975). "Uncovering nondiscernible" differences: Empirical research and the jurysize cases. Michigan Law Review, 73, 643.

Lempert, R. O., \& Saltzburg, S. H. (1982). A modern approach to evidence (2nd edition). St. Paul: West Publishing Co.

McCloskey, M., \& Egeth, H. (1983). Eyewitness identification: What can a psychologist tell a jury? The American Psychologist, 38, 550-563. 